\title{
Inside shadow banking: understanding the doomsday machine
}

\author{
Wesley C. Marshall* \\ Departamento de Economía, Universidad Autónoma de Metropolitana - Iztapalapa, México
}

\begin{abstract}
This article will argue that the shadow banking system has been at the heart of the Great Crisis since its first manifestations in the summer of 2007. This system has been purposefully misunderstood, as it is essentially a complex machine of too-big-to-fail banks designed to make large private profits while creating infinitely larger amounts of public debt. Years into the crisis, the shadow banking system still presents the greatest threat to global financial stability. As the fundamental operational conditions of this system gradually become clearer, and the understanding of the risks greater, a proper understanding of shadow banking is essential if the enormous problems of this doomsday machine are to be resolved.
\end{abstract}

Keywords: shadow banking, financial crises, investment banking, international financial markets

JEL classifications: $G 01, G 24, G 15$

\section{INTRODUCTION}

The shadow banking system (SBS) has been at the heart of the current Great Crisis since its first clear manifestations in 2007. Yet even as shadow banking continues to pose ever greater threats to global financial stability, several of the sector's most fundamental operational characteristics remain largely absent in financial literature. This omission is not entirely coincidental, as the structure of the SBS is intentionally complex in order to obfuscate its primary function: ex-nihilo credit-money creation through the origination and distribution of derivatives and structured financial products of often doubtful value. Analysing the SBS is further complicated through many academic articles that heap deliberately misleading analysis on top of an already complex object of study. In contrast to many such studies, this article strives to offer a simple yet robust analytical framework capable of capturing the most important dynamics of the highly connected US and European SBS. Once the object of study has been established, the recent evolution of the global financial system will be analysed through the lens of the SBS.

This article is divided into three parts. The first (Section 2) attempts to cut through the thickets of academic literature and arrive at a basic understanding of the SBS. Two basic premises are used as machetes in this case. This first premise, paraphrased from J.K. Galbraith, is that there is nothing new under the sun in banking; there are only so many ways in which banks can create ex-nihilo credit-money. The second premise is the celebrated phrase of Michael Kalecki, that 'economics is the science of confusing

* The author would like to thank the anonymous referees for their many insightful critiques. The usual disclaimers apply.

Received 7 October 2013, accepted 23 April 2014 
stocks with flows'. Through a discussion and critique of current literature on the subject, the paper arrives at a working definition of the SBS.

Section 3 analyses the role of the SBS in the lead-up to the Great Crisis and during its onset. Academic literature claims that Paul McCulley coined the term 'shadow banking system' in 2007. True or not, the evolution of the SBS certainly outpaced academic investigation. Only with the luxury of a few years' hindsight has the dominant role of the SBS in the gestation of the current crisis begun to be amply explored. There exists nearconsensus even in non-critical specialized literature that the seizing up of the SBS's flows was the proximate cause of the Great Crisis. This rather surprising agreement hides deeper concerns over the SBS, which, once again, have begun to be understood only years after the onset of the crisis.

Section 4 deals with these deeper concerns - particularly those revolving around the dynamic of rehypothecation. Yet again, with the benefit of hindsight, both crucial events during the crisis and the response of authorities can be understood in the light of an SBS that has amassed mountains of debt with virtually no backing by any real assets and which are far in excess of all global economic capacity to absorb. In the conclusion (Section 5), the possibilities to disconnect this 'doomsday machine' will be discussed.

\section{WHAT IS THE SHADOW BANKING SYSTEM? A CRITICAL VIEW OF THE EXISTING LITERATURE ON THE SBS}

Ample literature now exists on the subject of shadow banking, and it can be roughly characterized into two groups. The first consists of the research conducted by institutions with a direct stake in the financial sector, such as the New York Federal Reserve (FRBNY), the International Monetary Fund (IMF), the Bank for International Settlements (BIS), the Organisation for Economic Co-operation and Development (OECD), Fitch Ratings, and many mainstream academics. The second consists of relatively independent academics who critically analyse finance (Jeffers/Plihon 2013; Rehault 2013). Both groups offer valuable insights into the SBS. The critical authors in many cases correctly identify prominent characteristics of the SBS and place them into the analytical framework of the existing literature of critical finance. For their part, the group of official or officialist authors offers important insights into the specific operations of a very complex financial system. Taken together, the general public therefore has at its disposal both a 'forest' and a 'trees' set of analyses that are highly complementary. However, important gaps remain in both the 'forest' and 'trees' literature; both overwhelmingly consider the flows of the SBS while largely disregarding its stocks, and neither directly addresses the core issue of how the SBS creates ex-nihilo credit-money.

Both groups place a great deal of emphasis on how the SBS broke down in 2007 and 2008 , which is certainly more than justified. When the financial flows relating to the SBS froze during this period, it set in motion a series of disruptions in the global financial system that could only be temporarily overcome by government intervention. However, by focusing on the flows of the system and the consequences of its disruptions, the larger picture was lost: the SBS created enormous amounts of now worthless debt. While a large part of these losses have yet to be realized, the amount of public assistance necessary to maintain the minimal amount of financial flows to keep the SBS from collapsing is testing the financial and political limits of many of the globe's most relevant central banks. Along with the rise to prominence of several key aspects of the SBS that were largely unknown at the time of the SBS's 2007 'heart attack,' it is now clear that the successful attempts to maintain the global financial system's operations through the most dire moments of 
financial panic came at the very high cost of keeping the SBS largely intact. As this paper will attempt to show, what has been aptly named the 'doomsday machine' was not unplugged, and continues to represent the greatest threat to the global financial system as currently constructed and organized.

A very revealing fact about the SBS is that it is shrouded in such secrecy and confusion that there is no clear definition of what it even is. Many have called shadow banks 'non-deposit taking financial institutions,' while others refer to them as 'non-bank banks.' Such definitions are nonsensical due to the fact that they hide what shadow banking actually entails. A more honest and straightforward definition would be that shadow banks are private financial entities that create ex-nihilo credit-money ${ }^{1}$ without deposits. Such a generalization is problematic for many, however, as the following question would have to be: how do they create this money?

As both Gorton (2009) and Cetorelli/Peristiani (2012) insightfully mention, at least since Frank Capra's It's a Wonderful Life, the attentive American public have been given enough insight to recognize that deposits often are accounted for as being present in bank vaults when they really are not. Under the erstwhile buy-and-hold banking model, illiquid assets and liquid yet largely absent deposits were locked into mutually dependent relations. Yet, from personal experience, including movies ingested, no Americans can remember the day in which banks created money essentially out of thin air without using deposits. However, history clearly shows a simpler form for banks to create ex-nihilo money. When banks issued their own bank notes, they usually held capital, typically gold, silver, and state bonds (or any given combination) to back their monetary emission. A cautious bank, therefore, could issue $\$ 10$ from $\$ 1$ 's worth of gold. A less cautious bank, could, for example, issue $\$ 100$ from the same backing, while an even more reckless bank could issue its own money with no backing at all. Shadow banking is essentially dusting off this old trick. One of this paper's central arguments - that there are only so many ways banks can create ex-nihilo money - finds backing in J.K. Galbraith's writing:

The world of finance hails the invention of the wheel over and over again, often in a slightly more unstable version. All financial innovation involves, in one form or another, the creation of debt secured in greater or lesser adequacy by real assets. This was true in one of the earliest seeming marvels: when banks discovered that they could print bank notes and issue them to borrowers in a volume in excess of the hard-money deposits in the banks' strong rooms. The depositors could be counted upon, it was believed or hoped, not to come all at once for their money. There was no seeming limit to the debt that could thus be leveraged on a given volume of hard cash. A wonderful thing. The limit became apparent, however, when some alarming news, perhaps of the extent of the leverage itself, caused too many of the original depositors to want their money at the same time. All subsequent financial innovation has involved similar debt creation leveraged against more limited assets with only modifications in the earlier design. All crises have involved debt that, in one fashion or another, has become dangerously out of scale in relation to the underlying means of payment. (Galbraith 1990: 20)

Shadow banking does not escape Galbraith's pithy synthesis of the monetary creation capacities of banks and their devastating consequences if left to expand beyond their means. Indeed, the world has never seen such an unstable version of financial innovation or such a scale of monetary creation with so little backing it. Yet if banks have simply

1 Whether this is money or not can certainly be debated. For reasons of space, this article adopts the stance of Sawyer (2013) and will use the terminology of credit-money. This is sometimes shortened to just 'money,' out of consideration for the article's readability. 
shifted the ex-nihilo money-creation machine from one that involves the accounting manipulation of deposits to one based on ignoring capital levels, then why is most analysis of shadow banking so convoluted?

The system's complexity surely has to do in part with its own evolution, but it also serves to hide what is essentially an inherently fraudulent scheme of financial alchemy. On the first point, Gorton presents the fairly standard historical narrative that the originate and distribute banking system, operated through the structures of the SBS, evolved out of the buy-and-hold model due to changing market structures, specifically the emergence of money market mutual funds (MMMFs), and the rise of products such as junk bonds (Gorton 2010: 4). Reaching maturity, the SBS would allow banks to sell assets for up-front fees as opposed to realizing relatively little profit on these assets as they matured. Those assets that were still held by banks in the run-up to the crisis were likewise in large part held off-balance-sheet in entities such as structured investment vehicles (SIVs), to avoid having to hold reserves against potential losses.

Yet as the SBS grew and evolved, and as its main function as a complex ex-nihilo money-creating machine became ever more overt, even prime defenders recognized this central feature. On this second point, the declarations of Schwarcz (1994) are of particular interest. Arguing that 'securitization is an alchemy that really works,' Schwarcz makes the case that off-balance-sheet accounting is necessary; as 'securitization is usually viewed, for accounting purposes, as a sale of assets and not as financing, the originator does not record the transaction as a liability on its balance sheet. Such off balance sheet funding thus raises capital without increasing the originator's leverage or debt-to-equity ratio on its financial statements' (Schwarcz 1994: 142-143). Schwarcz states that 'this change of form is not to mislead investors' (ibid.).

Actions taken by prominent actors in the SBS would certainly come to contradict this statement, as will be analysed later. Yet the argument that the development of the SBS was an innocuous evolution driven by diminishing profits in traditional banking is weakened by the very way in which the SBS has been presented. While Schwarcz lawyerly evades an explicit recognition of the virtually unlimited off-balance-sheet debt creation that he describes in his article, he does introduce elements of clarity in his description of the SBS, particularly in its capacity to create ex-nihilo credit money, as opposed to many other publications, which are much more successful in obfuscating the object of study. Such attempts would certainly be in order, particularly considering the immense levels of debt that the system has created. As mentioned, most of the more relevant academic publications regarding shadow banking have added to the confusion through focusing on the incredibly complex flows of the system, rather than clarifying the shadow banking sector through the analysis of its most important results in terms of the stock of assets of dubious value financed by debt.

Perhaps the clearest example of this phenomenon is a paper written by Pozsar et al. (2010) from the FRBNY. By all accounts, the chart that the authors created to visualize the flows of the SBS (Figure 1) is not in itself misleading, yet it is utterly baffling. Great attention is given to the flow of the system, but none is given to the stock of bad debt created. The authors present the SBS as a sort of complex production line in which diverse actors contribute different elements to the continual flow of the system, yet while giving little or no consideration to what the system is actually making. In this case, the undisputable finality of the SBS is the production of debt and profit. If analyses such as those of Pozsar et al. considered the end product of the system, instead of a complex two-dimensional flowchart on the horizontal plane, we would see an extremely simple three-dimensional chart, with growing piles of profit rising out of the system and mountains of debt sinking downward, both on the vertical plane. 


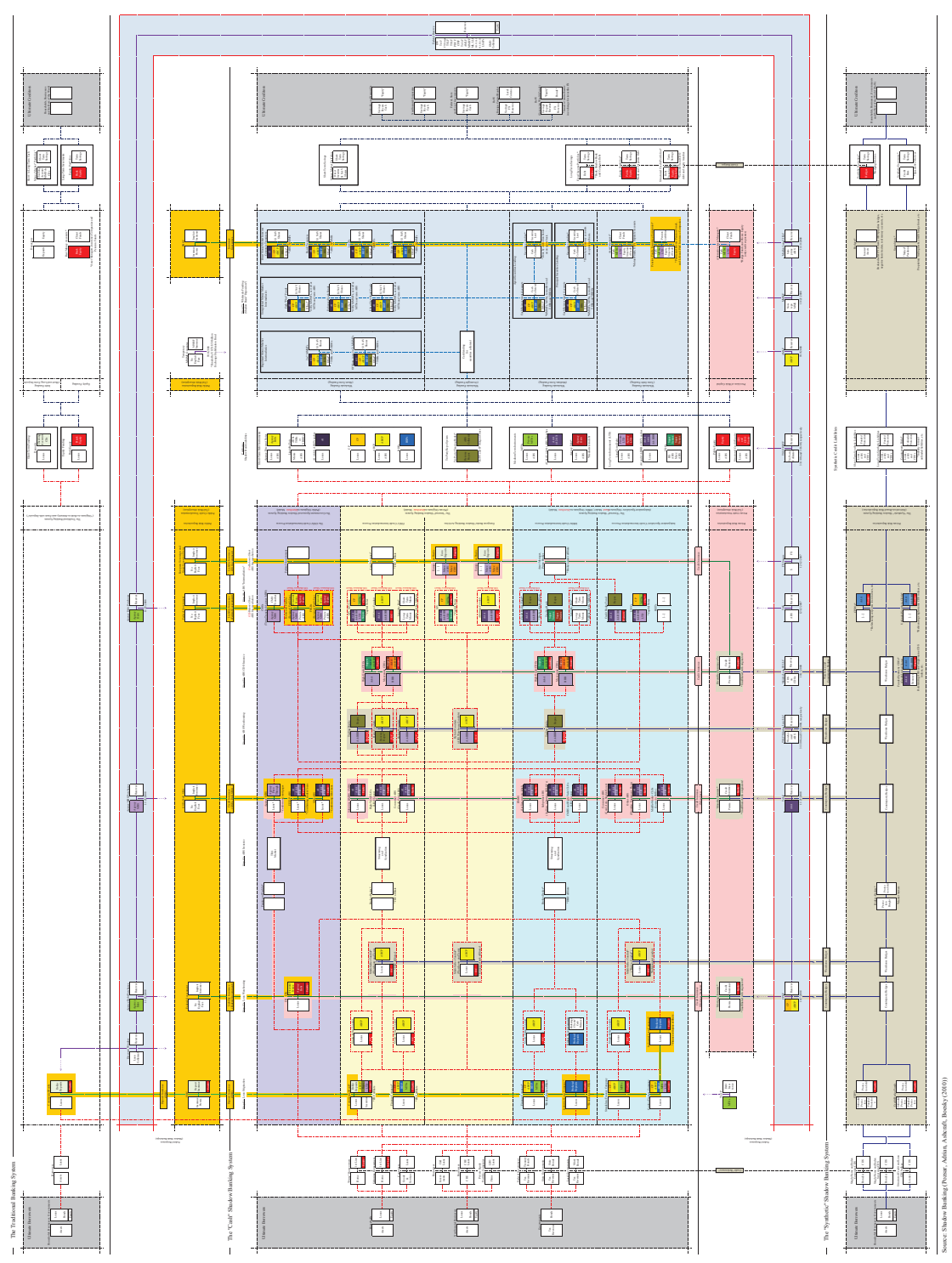


Upon publication, Pozsar et al.'s paper was significant not only in that it was the first thorough treatment of the flows of the SBS to be amply diffused, but also because it reached what first appeared to be a quite controversial conclusion, namely that 'some segments of of the shadow banking system have emerged through various channels of arbitrage with limited economic value' (Pozsar et al. 2010: 67). The IMF also released a similar statement, that 'some complex and multi-layer products added little economic value to the financial system. Further, they likely exacerbated the depth and duration of the crisis by adding uncertainty relating to their valuation as the underlying fundamentals deteriorated' (IMF 2008). An even stronger damnation of certain financial activities under which the SBS clearly falls comes from the OECD, which in its 2011 paper Bank Competition and Financial Stability, states that:

In very broad terms, there are two quite different types of financial products:

1. Those primary instruments associated with consumption, savings and fixed capital formation that create wealth (usually associated with loans for trade credit and working capital, and securities - equity and debt); and

2. Those associated with wealth transfer between economic agents in the attempt: to hedge risks; to arbitrage prices, to gamble; and to reduce tax, regulatory and agency cost (management fees, custody, brokerage, etc.) (OECD 2011: 36).

That the FRBNY, one of the chief enablers of the financial crisis (Black 2009), as well as the IMF and OECD, two stalwart champions of unregulated financial activities, should come out so strongly against the financial activities of the SBS, certainly appeared strange to many observers, particularly as many mainstream economists eagerly deemed the financial crisis to have been largely over. Yet one key omission from both institutions' publications is exactly what this article contends is the prime objective of the SBS virtually unlimited ex-nihilo credit-money creation. Leaving aside the 'doomsday machine' aspect of the SBS to focus on lesser sins such as fraud and speculation would appear to be a diversionary tactic by these institutions.

\section{EX-NIHILO CREDIT-MONEY CREATION BY INVESTMENT BANKS PRIOR TO THE CRISIS}

Roughly 2 years after Pozsar et al. published their paper through the FRBNY, Cetorelli/ Peristiani (2012), also writing for the FRBNY, take a second stab at the SBS, with quite different results. While Pozsar et al. state that "we use the label "shadow banking system" for this paper, but we believe that it is an incorrect and perhaps pejorative name for such a large and important part of the financial system' (Pozsar et al. 2010: 4), Cetorelli/ Peristiani are much more direct in saying that 'intermediation has moved off the banks' balance sheets and into the shadows' (Cetorellia/Peristiani 2012: 48). While not going so far as mentioning ex-nihilo credit-money creation, the latter authors are much more forthright in identifying the essence of the SBS and the appropriateness of its name. At the same time, these authors also cut through Pozsar et al.'s confusing description of the actors in the system. Pozsar et al. state that 'examples of shadow banks include finance companies, asset-backed commercial paper (ABCP) conduits, limited purpose finance companies, structured investment vehicles, credit hedge funds, money market mutual funds, securities lenders, and government-sponsored entities' (Pozsar et al. 2010: 1). Much like the complexity of the flow of funds hides the stock or end results of the system, the abundance of actors and their multiple relationships within the system, while real, 
also obfuscates the fact that the profits and the debt created by the SBS, and the management of these, are all 'dominated' by commercial and investment banks, ${ }^{2}$ in the words of Cetorelli/Peristiani (2012: 48).

Identifying investment banks as the principal actors in the production of debt and profits is a key first step in understanding the SBS, yet it is relatively simple compared to the second step: understanding the nature and magnitude of investment banks' relationships with hedge funds, structured investment vehicles (SIVs), collateralized debt obligations (CDOs), and other entities that are connected to investment banks to highly varying degrees. In other words, if investment banks are the core actors, and offbalance-sheet special purpose vehicles (SPVs) are their satellites, ${ }^{3}$ what is the relationship between the two types of entities? Reading the financial press, the interested observer would come to the conclusion that entities such as CDOs are relatively monolithic entities. Much like a Mortgage Backed Security (MBS) tranche, a bank would issue a $\mathrm{CDO}$ and then pretty much leave it alone. Yet, as Cetorelli/Peristiani (2012) show, such structured products have evolved towards an ever greater degree of management. Without even speaking of the many different types of CDOs - CDO squared, synthetic CDOs, etc. - a distinction can certainly be made between those that are inert in nature, approximating bonds, and those that are much more active in nature, much more closely approximating an investment fund. Such variety is in part captured by legal terms:

An SPV can take the form of a corporation, trust, partnership, or a limited liability company. The SPV may be a subsidiary of the sponsoring firm, or it may be an orphan SPV, one that is not consolidated with the sponsoring firm for tax, accounting, or legal purposes (or may be consolidated for some purposes but not others). (Gorton/Souleles 2007: 555)

As will be shown, relationships between managed off-balance-sheet entities and their creator banks can become incestuous and problematic. One of the more insightful visualizations of the evolving relationship between investment banks and the degree to which a variety of financial entities that could be grouped under the families of SPVs and hedge funds were in their orbit, was given by Gillian Tett (2009), who used the metaphor of a bank placing these investment funds in their cellar or in their garage, depending on the convenience of doing so. Expanding slightly on her metaphor, we could think of the banks keeping SPVs in their garage - off-balance-sheet but with relatively visible operations - while they are operating well, and then pushing them into the cellar when they stop performing. Hedge funds can be internal or external to a bank, with their official and unofficial relationship often determined by a similar dynamic. To the issue of both the relationships between banks and their unregulated investment vehicles, and the cellar and garage metaphor, we will return later.

Before that, a brief examination of the facility that banks have in choosing whether an asset is on or off balance sheets is in order. While the complex and differing relationships between the actors that constitute the SBS and their financial assets have received a great deal of attention, and rightly so, the foundation of the SBS's current complexity was not constructed upon financial specialization in itself, but rather upon an enabling regulatory environment. Without off-balance-sheet accounting, shadow banking is impossible. If properly accounted for, structured products and derivatives would all have to be backed

2 As all bank involvement in the SBS consists of activities that fall under broad definitions of investment banking, for reasons of simplicity this article will call such banks investment banks, even if their legal denomination is now otherwise.

3 Financial and academic literature in general groups entities such as SIVs, CDOs, CLOs, etc., under the term SPVs. 
by liabilities or capital. Once again, shadow banking's money creation is based on eschewing capital requirements. Investment banks have simply created hundreds of trillions of dollars in assets without adequate backing by real assets, as mentioned in the opening quote from J.K. Galbraith. Many economists and members of the financial press seem to have fallen into an unquestioning comfortability with regard to these unfathomable numbers. The total of outstanding structured financial products varies to a high degree between studies, but is in the tens of trillions. The more known figure regarding unfunded assets of the SBS is the roughly $\$ 650$ trillion derivatives market. Any common-sense analysis of the explosion in these numbers in the decade prior to the crisis would arrive at the only possible conclusion, that they are not backed by anything. Neither bank deposits nor bank capital expanded exponentially in line with Shadow Banking assets.

However, MMMF assets also did experience a significant, yet notably lesser increase during the same period. MMMFs create ex-nihilo money in the repurchase market in an analogous way to multiplying deposits. By investing the day-to-day surpluses of large firms in short-term bonds, institutional MMMFs provide large firms with a place to park excess funds, and offer their clients a portion of the returns on securities. By calculating the probable outflow of client funds, MMMFs can purchase assets in excess of liabilities. In comparing MMMFs to deposit-taking banks, Gorton/Metrick (2010) put forth an enlightening analysis of the flows of the system, but do not go into depth on the stocks of the system.

This is also understandable, as MMMFs invest in the liabilities issued by CDOs and SIVs in addition to T-bills and other instruments, but do not take equity positions in CDOs or SIVs, nor did they they create them. MMMFs are very much interwoven in the SBS, but they act basically as financial intermediaries that regulate the flow and indeed increase it, but only influence the stocks of the system in the sense that many parts of the SBS would surely not have been created had there been no mechanisms in place to attend to its flows. MMMFs can therefore be seen as indirect and not direct contributors to the stock of the SBS. As Gorton (2010: 510) argues, all they do is essentially lend at 3 percent at invest at 6 percent.

\subsection{Magnetar and Abacus}

First, the problematic relationship between investment banks and their satellite entities merits further emphasis, which is provided by two illustrative cases, Goldman Sachs's (GS) CDO Abacus and the hedge fund Magnetar. The first case, which served as a vehicle for GS's profitable purging of its toxic waste, is representative of many CDOs based on residential mortgage-backed securities (RMBS), in that it represented a successful transfer of risk that mainstream analysis has highlighted as one of the more, if not the, most useful function of the SBS. However, in this and many other cases, risk transfer could be more accurately described as a front and back end fraud. Black's (2010) research presents RMBS during the inflation of the housing bubble as being almost entirely constructed upon fraudulently issued mortgages. On the front end, the sacrificed future personal finances of many individuals were turned into the RMBS upon which many CDOs were structured, and on the back end, investors in these designed-to-fail structured products were left holding the bag. Such considerations, confirmed by the FCIC (2011) highlight that permitting investment banks to ignore all capital requirements was not the only aspect of the regulatory framework that enabled the exponential growth of the SBS. Such historical events underline the fact that the regulatory framework that enabled the exponential growth of the SBS was not merely passively permissive. Allowing the three dominant ratings agencies to act as risk managers for the SBS and its clients, and their fraudulent form of operation, were likewise conditions without which the SBS could not perform its alchemistic functions. 
The fact that Abacus could obtain an AAA rating was among the most egregious transgressions of the ratings agencies, as the Abacus CDO was created out of RMBS tranches hand-picked by hedge fund manager John Paulson for what he thought was their high probability of defaulting. As the Abacus $\mathrm{CDO}$ was made to explode in someone else's hands, GS took out Credit Default Swaps (CDSs) on Abacus. This dynamic has been used by other TBTF banks such as Citigroup, JPMorgan Chase, and others (Scannell 2013). The net result in the Abacus case was entirely positive for GS, yet entirely negative for both mortgage holders and for investors who bought into the CDO. Interestingly, it was also negative (at least transitorily) for those who sold CDSs to GS. This point merits a brief parenthesis.

Derivatives are a fundamental ingredient in the SBS in two important ways. First, derivatives grease the wheels for transactions involving structured products, as 'insurance' can be taken out against the possibility of the product entering into default. It is worth remembering that currently only four banks issue just over 93 percent of all derivatives in the US (OCC 2013), and that the three dominant ratings agencies enjoy close relationships with the same banks; a key element in understanding how assets rated in less than flattering terms by their own creators could be classified as AAA and offloaded onto greater fools. Second, derivative contracts, in their great majority of the non-regulated over-thecounter kind, can be written with no backing from balance sheets, effectively allowing derivative dealer banks the power to make unlimited unfunded bets, often tied to the SBS's structured products. The most prominent proof of this practice did not even come from a bank, but rather from AIG's Financial Products Corporation, operating out of London, which issued CDSs with no backing whatsoever (Lewis 2010). Also taking into consideration the fact that insurance can be taken out against other people's property, the only logical conclusion is that CDSs are not insurance, but rather are unfunded one-way bets, or, in other words, off-balance-sheet ex-nihilo credit-money creation.

Many analysts claim that when looking at derivatives numbers, real values should be considered rather than notional values, as the latter simply aggregate bets that could cancel themselves out. Yet when highlighting the effortless creation of ex-nihilo money, the notional figure certainly is the more relevant. Regardless of whether one actor's bet will cancel out another actor's bet, each bank would have to offset the bet on its balance sheet under a more transparent accounting regime. In addition, opposing bets may mathematically cancel each other out, yet this equation rests on the assumption that all bets are effortlessly cleared: a far from guaranteed outcome in real life.

The Magnetar trade is revealing in similar ways. While 'key details of the Magnetar trade remain shrouded in secrecy' (Eisinger/Bernstein 2010), ProPublica's investigation of the hedge fund that was crucial in the creation of 30 CDOs reveals several crucial elements of the relationships between formally independent hedge funds and investment banks. As Magnetar was a willing buyer for the lower-rated tranches of CDOs - the most difficult for investment banks to sell - it was considered a 'sponsor' of such deals. Magnetar was also betting against many of the structured products that it purchased, but through its purchases, it was a key institution in allowing investment banks to keep the CDO production business humming in its waning days, particularly as most of its purchases took place after housing prices had begun their secular decline (ibid.).

The Magnetar and Abacus examples are useful to understand the great deal of diversity of functions among the many and diverse players of the SBS. Yet while investigative reporting has brought some activities out of the shadows, such great diversity and complexity preclude many sweeping generalizations about the roles of many actors in the SBS. At the same time, the lack of both systemic and specific information regarding the SBS, coupled with its great deal of diversity and complexity, means that wider studies that depend on relatively accurate and large data sets may never come. 
However, for the purposes of this paper, there fortunately is a fairly accurate set of guidelines to generalize which parts of the system create ex-nihilo credit-money at which point in complex chains of transactions. Yet for the above reasons, this guideline, shown as Figure 2, is more easily understood with additional considerations of ex-nihilo creation capacity at each step. The first step is to clear up the title of this figure, taken from Claessens et al. (2012). Rather than financial intermediation, this figure tracks exnihilo credit creation in the SBS. Besides this slight change, the figure corresponds to this article's description of the SBS and is useful for tracing money creation within the system.

Investment banks are rightly at the center of Figure 2. They create SPVs. As their name implies, SPVs are a vehicle for money creation, but their creation in itself does not necessarily involve money creation. This only occurs as the empty vehicle becomes filled. The main credit creation mechanism of the SBS is issuing loans, whether they be in the form of mortgages, corporate real estate, or leveraged buy-outs. So in this first step of money creation, on the upper left, credit is issued to the ultimate buyers. If we take the example of a subprime loan, the only counterpart to the credit creation is the downpayment on the mortgage, as these loans are ultimately off balance sheet. If we have a pool made up of mortgages with no downpayments, then we have 100 percent money creation.

The next step in the money creation can be seen in the bottom-left-hand portion, as the mortgages are now packaged into an SPV, and sold to investors. The purchase of an equity position in, let's say, a CDO consisting of subprime mortgages, does not necessarily involve money creation, as a saver can simply buy the position. Yet, as Figure 2 shows, an investor can borrow the money from the investment bank. Indeed, the purchaser may even be the same bank. In this case, an internal hedge fund may buy the position with no backing capital. As the Magnetar case showed, many purchases that appeared external when transacted, were later shown to be far from arm's length.

Once the SPV has connected ultimate borrowers (households in our example) with what the figure accurately generalizes as leveraged investors, the CDO is now up and running, and the right-hand part of the chart comes into play in step three. In the upper portion, we find the SPV (again in our case a subprime CDO) selling short-term paper in the ABCP market. This is familiar ex-nihilo credit creation, as it is simply the issuing of short-term securities that monetize future cash flows.

This monetary creation is complemented by that of step four, in which investment banks, acting as dealers, lend to MMMFs, which, as described, can lend in excess of their deposit base. We therefore have four points of money creation in Figure 2. In general terms, we can say that the left-hand chart represents the stocks of the systems - the ultimate borrowers, as the figure states. On the right-hand side of the chart, we have the flows of the system.

Yet, as warned, Figure 2 needs some further explanation for the purposes of this paper. First, there are two key steps of money creation in the SBS that are missing. The first is that the dealer banks not only fund MMMFs through the repo market, but also hedge funds, which often leverage a large portion of their purchases through bank borrowing. As will be examined shortly, if haircuts serve as the only counterpart to dealer lending to hedge funds, and this collateral is then recycled through rehypothecation, there are practically no limitations to money creation. Second, the derivatives that are sold as complements to equity positions taken in structured products are also missing. As derivatives are sold off-balance-sheet, the transaction is pure money creation minus the collateral offered by counterparties, called margin.

Again, Figure 2 can easily lead to oversimplification. In four out of the six identified moments of SBS ex-nihilo money creation included in the figure, we cannot clearly divide 

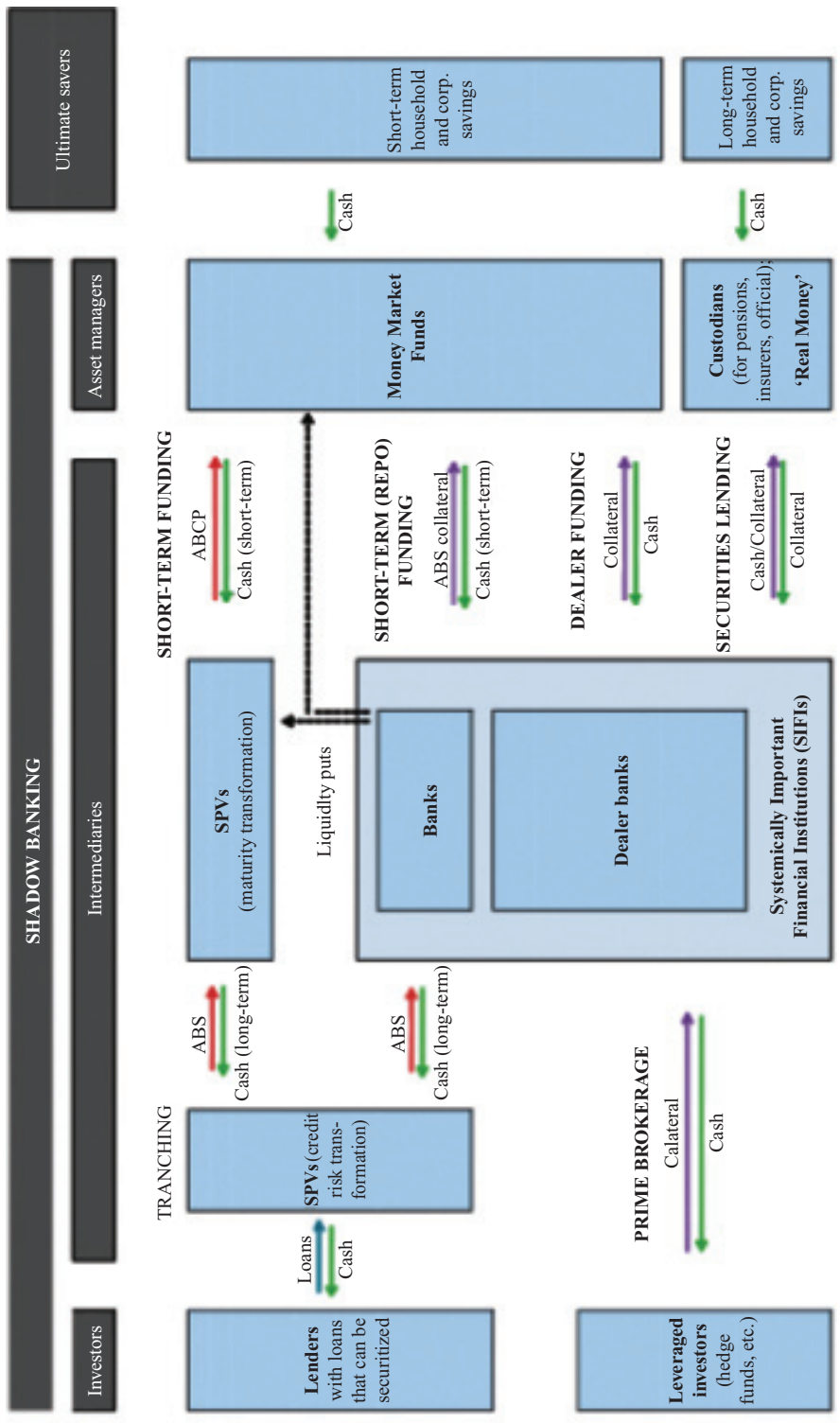

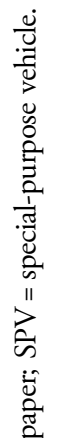

$\frac{2}{3}$
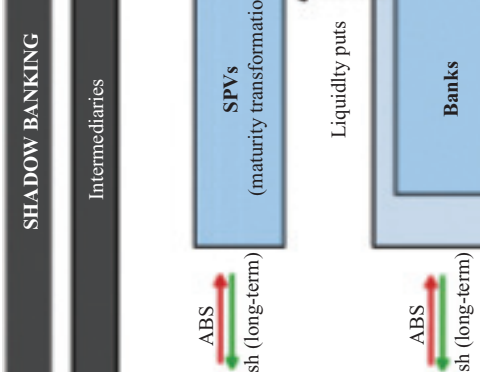
between stocks and flows. Real profits are made at each point of monetary creation. This must be seen as a stock that is removed from the system. However, on the left-hand side of the chart, assets are of longer term; monetary creation and extinction are measured in years, whereas on the right-hand side of the figure, money is created and extinguished fairly quickly, usually measured in weeks if not days. It is therefore probably more accurate to describe profits as the system's stocks, while the flows can be divided into longer and shorter term debt repayment. Yet, as the SBS has created assets that will never be paid off, these should also be counted as stocks. Complicating matters further is the relationship between the degree of leverage used and the chances of a loan being repaid. This is particularly true of derivatives. The $\$ 650+$ trillion outstanding derivatives contracts is certainly a scary number. But most derivative contracts are offsetting and are often offset through clearing houses.

Again, this article is an initial attempt at clarifying the workings of the SBS, still very much in the shadows. Fitch Ratings (2012: 1) state that 'despite the systemic importance of repo markets, granular information about haircut, collateral, and counterparty trends is relatively scarce'. The same can be said about the entire SBS: despite its great importance to the global economy, very little specific information is available. The SBS not only exists in the shadows of accounting and regulatory control, but also in the shadows of information and academic study.

\section{REHYPOTHECATION}

The presentation of the SBS as a vehicle for the ex-nihilo creation of piles of profits and mountains of $\mathrm{debt}^{4}$ has left out a crucial limiting factor in this growth: collateral. Although prudential regulation did not limit investment banks' creation of credit-money in the form of complementary derivatives and structured products, the discipline of the market did, to a certain extent, as the sale of structural financial products was partially backed by collateral. Although the ratios vary widely between individual transactions, a haircut of 5 percent appears to be the norm in the repo market; Fitch Ratings state that 'a derivative with a $5 \%$ margin requirement provides $20: 1$ leverage. A repo requiring a 5\% haircut provides 21:1 leverage'5 (Fitch Ratings 2012: 2). A 20:1 leverage limit would provide the SBS with a fairly normal degree of market discipline, as recently failed institutions have had much higher leverage ratios upon their demise. However, this is not the case in the SBS, which permits collateral to be re-used, or rehypothecated. Therefore, when a hedge fund pledges $\$ 10$ of collateral, its prime broker can turn around and pledge the same collateral for its own bets. The IMF estimated in 2011 (Singh 2011) that, on the average, assets were rehypothecated three times, meaning that in any given time, a financial entity's capital cushion against losses could be estimated at one-third of the 5 percent of collateral pledged. However, as will be seen, the dynamics of rehypothecation create situations in which real levels of leverage are impossible to know.

4. 'For CDOs that focused on the relatively senior tranches of mortgage-backed securities, annual manager fees tended to be in the range of $\$ 600000$ to $\$ 1$ million per year for a $\$ 1$ billion deal. For CDOs that focused on the more junior tranches, which were often smaller, fees would be $\$ 750000$ to $\$ 1.5$ million per year for a $\$ 500$ million deal' (FCIC 2011: 131).

5. As Singh (2011) notes, assets can be pledged through direct collateralized lending or through repo market related financing. Fitch Ratings' estimates are based on the latter. Figures regarding the former are not readily available, but due to the complementarity of the two forms of financing, the repo market ratio is representative. 
While high rates of leverage have proved catastrophic in the past, rehypothecation adds a further troubling element. As rehypothecated assets are held off-balance, many financial institutions can hold the same asset simultaneously. So not only are credit buffers extremely thin, but they may not exist at all at any given time. In this sense, rehypothecation is similar to fractional reserve banking, as accounting tricks allow banks to equilibrate balance sheets (or in the former case, hide them off-balancesheet); but while in the buy-and-hold banking system deposits were leveraged, in the SBS it is capital being leveraged. Although both deposits and rehypothecated assets have proven evanescent in moments of panic, the fact that capital buffers may disappear instantaneously and simultaneously in different financial actors represents a very worrying phenomenon.

A clear diagnosis of the problem is therefore essential. While some analysts, such as the financial blog ZeroHedge, which has had excellent coverage of the SBS and the issue of rehypothecation, have confused the latter as a play on deposits, others have recognized, at least to some extent, that it is rather a play on capital. Gorton (2010) hints at the similarities between rehypothecation and the leverage of bank capital during the wildcat banking period. Yet, as will be shown, the logical consequences of this line of thinking are too dire for many to contemplate. But Gorton's hints are backed by other accounts of the period, perhaps most famously that of J.K. Galbraith (1975):

Also put in circulation, just in advance of the commissioners, was the gold and silver that served as the reserve. This was moved in boxes from bank to bank; when required, the amount was extended by putting a ballast of lead, broken glass and (appropriately) ten-penny nails in the box under a thinner covering of gold coins. One of the enforcing commissioners, with the ever-present gift for metaphor of the age, complained that 'gold and silver flew about the country with the celerity of magic; its sound was heard in the depths of the forest, yet like the wind, one knew not whence it came or whither it was going.' (Ibid.: 87-88)

Within the SBS, therefore, rehypothecated collateral is what serves as the gold and silver (or ballast). In both cases, capital buffers are in place in all places where authorities or other interested parties look for them, but they are in fact not there in most cases. In the case of shadow banking, regulators have openly given the green light to this practice. Just as TBTF banks have been able to avoid traditional capital requirements of regulatory authorities through off-balance-sheet accounting, they have also evaded the market's capital requirements of collateral through rehypothecation. Both are examples of ex-nihilo credit-money creation by omitting capital requirements.

While outmaneuvering regulators is certainly a constant of the bank-led monetary expansion and fraudulent activity (Kindleberger 1989) that has led to untold numbers of individual bank failures and banking crises through the years, the complicity of the authorities in the growth of the SBS has led to a far more dangerous scenario: the creation of what has been aptly named the doomsday machine, which today appears to be escaping the control of the authorities that aided and abetted in its creation.

The complicity of US authorities has been well documented, particularly the comments of Alan Greenspan, who, while serving out his last years as the Chairman of the Fed, famously stated that 'recent regulatory reform, coupled with innovative technologies, has stimulated the development of financial products, such as asset-backed securities, collateral loan obligations, and credit default swaps, that facilitate the dispersion of risk' (Greenspan 2005). Again, the SBS cannot exist without authorities permitting off-balance-sheet accounting.

When the ABCP market collapsed in August of 2007, signaling the beginning of the Great Crisis, the authorities' first response was to fight fire with fire. As SIVs (along with 
hedge funds and CDOs) began to collapse, these entities were to be grouped together under the Master Liquidity Enhancement Conduit, a $\$ 400$ billion 'Super SIV,' an idea that was conceived between TBTF banks and financial authorities.

When this plan was abandoned shortly thereafter, the banks with the greatest SIV exposure moved the entities onto their balance sheets. Yet, to return to Tett's (2009) metaphor, this does not mean they were moved from the garage into the house. Rather, they were moved from a visible yet off-balance-sheet operation onto the balance sheet but in the cellar. The relaxation of fair value accounting rules from a mark to market standard allowed banks to freely designate assets between three levels, with the third level allowing banks to assign asset prices outright. This measure, taken together with the first round of bank stress tests in spring of 2009, marked a clear turning point for the US crisis. In the most official of ways, US authorities made clear to all that TBTF banks would not have to realize losses in the near future.

Around the same time, central banks also began accepting MBS and other structured products as collateral for central bank emergency lending. While many analysts considered that the crisis had been successfully resolved, the unconditional bailout of criminal banks cannot lead to a successful resolution, as these banks will simply pocket bailout money, greatly increasing its costs while doing little to restore credit (Marshall 2009). Instead of dismantling the doomsday machine that sparked the Great Crisis in 2007, authorities opted to leave it basically intact but hidden from public view. To return to Tett's analogy once again, authorities buried the entire system. What now appears to be the most significant Achilles' heel in the bailout period - rehypothecation - was not on anyone's radar in the run-up to the first round of the crisis. Indeed, even the most comprehensive review of the conditions leading up to the crisis, the Financial Commission Inquiry Report (FCIC 2011), has no mention of rehypothecation. While Gorton (2009) does cite several concerns voiced over potential shortages in collateral well before the Great Crisis, the first visible mainstream recognition only came in 2010, primarily through Singh/Aitken (2010), writing for the IMF.

Indeed, it was only with the downfall of MF Capital in 2011 that the immense problem of rehypothecation was revealed to active observers of finance. This case was dramatic for two reasons. The first is symptomatic of the TBTF phenomenon, in that the investment bank violated a fundamental law of not betting with clients' segregated accounts. Despite losing $\$ 1.6$ billion of client funds and not facing any criminal or civil charges for such a transgression, for the aims of this paper, the claims made by MF Capital that clients' funds had been 'vaporized' is much more interesting, as it offers potential insight into how the various attempts of US authorities to bury the corpse of the SBS in the basement have given rise to perverse consequences.

Given the loss of client funds, MF Capital's claims that the funds were 'vaporized' would appear to be a weak defense bordering on the absurd. However, in the context of collateral chains that become long and confused, it makes more sense. If a financial actor pledges collateral to another actor, and this collateral is re-used, let's say, ten times, and is counted by each actor as a present and full value asset for their internal purposes, what happens when the collateral defaults or is downgraded? ${ }^{6}$ When collateral is an outstanding liability, it can be freely passed around, but when it loses value, the scenario changes in a way similar to an extreme version of musical chairs. Before the music stops, everyone can claim a chair, but when the music stops, there is only one chair for ten people. The others are instantly vaporized.

6. When collateral used in repo markets loses value, its haircut increases. 
When mark to market standards were suspended, it was to halt a classic spiral of asset deflation that tends to occur once fraudulently priced assets are discovered and credit freezes, and allowed banks to ignore the downward evolution of assets shared throughout the system and keep counting their assets of declining value at their original value as if there were no crisis. Yet while assets that were really present but worth nothing can be counted at 100 percent of book value, there is no accounting treatment capable of confronting the simultaneous disappearance of assets that are not really there. Therefore, instead of steady albeit rapid lowering of prices, rehypothecated assets are vaporized in unison across institutions when the value of assets used as collateral loses value.

MF Capital, while representing the first victim of rehypothecation, was not alone in suffering this fate. After its bankruptcy, both ABN AMRO and Peregrine Financial Group have had similar experiences (Meyer/Stafford 2013). The fact that client funds were also lost in such incidents clearly points to a lack of internal controls at the adorementioned institutions, but it also points to the difficulties in managing long collateral chains. As will be shown, it is also possible that the previously undiscovered phenomenon of rehypothecation played a role in Lehman's bankruptcy (Olaoye/Elias 2011; ZeroHedge 2011).

Another relevant factor is the location of rehypothecation. In the US, existing rules state that assets can be rehypothecated only up to $140 \%$ of their value (Singh/Aitken 2010:4). However, English law has no such limitations, and London has become the black hole of global finance. AIG's CDS mess was operated through its London office, as was Lehmans' infamous Repo 105 - likewise for MF Capital's rehypothecation operations and JPMorgan's London Whale. According to the Financial Stability Board, bank assets in 2012 represent over 800 percent of UK GDP (FSB 2012: 12).

The dimensions of rehypothecated assets are staggering. According to Reuters, Morgan Stanley had $\$ 410$ billion of rehypothecated assets at the end of 2011, while JPMorgan had $\$ 546$ billion (Olaoye/Elias 2011; ZeroHedge 2011). Singh/Aitken (2010: 6) likewise calculate numbers of upwards of $\$ 800$ billion for several Wall Street banks at the end of 2007. Based on such information, Olaoye/Elias (2011) arrive at their 'terrifying alternative hypothesis' of the now various rounds of Quantitative Easing that the highly coordinated central banks of the US, Japan, UK and eurozone have unleashed. As of mid 2013, G7 central banks have injected somewhere around $\$ 12$ trillion into the global financial system in response to the crisis. Indeed, global markets have been pulled from significant selloffs during the past few years only through central bank intervention. As Juks (2012) documents, the European Central Bank's LITRO operation in the summer of 2011 created a dramatic increase in the proportion of encumbered bank assets (those pledged to other parties) in eurozone countries under official bailouts. Juks's figures therefore suggest that a significant part of central bank support is being used to close what has been measured as an $\$ 11.2$ trillion shortage of high quality collateral assets (Department of the Treasury 2013). Juks also emphasizes that once assets are encumbered, liquidity buffers for banks are consumed.

However, it is yet to be seen whether central bank quantitative easing programs, under various names, represent an adequate tool to confront the problem at hand. As central banks also require collateral in return for their financing operations, they run the risk of their bailouts becoming counterproductive in ways previously unseen, as these assets are now encumbered and cannot be re-used (ZeroHedge 2013). That is, of course, unless central banks are churning ${ }^{7}$ them as well. While not recognizing the depth of the problem of rehypothecation, the Bank for International Settlements all the same recognized that

7. In the jargon, churning is re-using. 
'central banks may wish to consider structural adjustments to their operations in the context of possible collateral shortages' (BIS 2013).

\section{CONCLUSIONS}

Given the size of the problem at hand, a correct diagnosis is necessary if correct policy options are to be developed. Whether the SBS is an accounting trick based on deposits or capital levels is therefore a key point. Gorton, one of the leading voices on the subject, has argued that the SBS is deposit-based, MMMF-led financial intermediation. By focusing the most relevant actors in the flow of the system, and not on the most relevant actors in the stocks of the system, the extent of the problem is greatly minimized.

As argued, it has been investment banks that were able to create mountains of debt and piles of profits. Yet during the exponential rise of the SBS, the TBTF phenomenon was well established. Therefore, debts could always be passed on to the taxpayer, while profits could be individually enjoyed. If MMMFs were at the heart of the SBS, Gorton/Metrick (2010: 508) correctly identify the key problem and its solution: 'the limits on the amount protected by deposit insurance make bank accounts inadequate for large depositors, such as institutional investors or nonfinancial firms. These investors and firms need a shortterm, safe, interest-bearing place to store money.' If a 'run on repos' were at the heart of the problem, some mechanism such as deposit guarantees would likely assuage the problem. The high figures of such an insurance scheme would certainly seem costly to some, but they pale in comparison to the issue of how to absorb tens of trillions of dollars in yet-to-be-realized losses by the world's largest banks.

As this article has argued, these losses are not only of staggering proportions, but will also multiply quickly once assets become distressed and simultaneously break collateral chains through a large number of investment banks and their satellite entities. Shutting off the doomsday machine will be infinitely more difficult than insuring corporate money in the MMMFs. The immense, de facto public debt that still lies hidden in the SBS exceeds all capabilities of globally coordinated government bailouts. Regulatory reforms have been enacted, yet until they tackle off-balance-sheet activity, their influence over the SBS will continue to be minimal. Perhaps the only solution is some type of debt jubilee among private actors. As SBS assets are relatively concentrated, this idea could be of some promise. However, as seen during the current bailout, prodding TBTF banks into collective action is problematic. Even more problematic, and highly symptomatic of the TBTF problem, is that if these entities correctly see the mountains of debt that they have created as a public liability, they have no incentive to sort it out.

\section{REFERENCES}

BIS (Bank for International Settlements) (2013): Asset encumbrance, financial reform and the demand for collateral assets, CGFS papers, 49, May, URL: http://www.bis.org/publ/cgfs $49 . \mathrm{htm}$.

Black, W. (2009): Interview, in: Bill Moyer's Journal, 3 April, URL: http://www.pbs.org/moyers/ journal/04032009/transcript1.html.

Black, W. (2010): Statement by William K. Black before the Committee on Financial Services United States House of Representatives regarding 'public policy issues raised by the Report of the Lehman Bankruptcy Examiner,' 20 April, URL: http://www.gpo.gov/fdsys/pkg/CHRG$111 \mathrm{hhrg} 57742 / \mathrm{pdf} / \mathrm{CHRG}-111 \mathrm{hhrg} 57742 . \mathrm{pdf}$.

Cetorelli, N., Peristiani, S. (2012): The role of banks in asset securitization, in: FRBNY Economic Policy Review, July, 47-63. 
Claessens, S., Pozsar, Z., Ratnovksi, L., Singh, M. (2012): Shadow banking: economics and policy, IMF staff discussion note, 4 December.

Department of the Treasury (2013): Fiscal Year 2013, Q2 Report, Office of Debt Management, URL: http://www.whitehouse.gov/sites/default/files/omb/budget/fy2013/assets/treasury.pdf.

Eisinger, J., Bernstein, J. (2010): The Magnetar trade: how one hedge fund helped keep the bubble going, in: ProPublica, 9 April, URL: http://www.propublica.org/article/the-magnetar-trade-howone-hedge-fund-helped-keep-the-housing-bubble-going.

FCIC (Financial Crisis Inquiry Commission) (2011): The Financial Crisis Inquiry Report: Final Report of the National Commission of the Causes of the Financial and Economic Crisis in the United States, Washington, DC.

Fitch Ratings (2012): Repo emerges from the 'shadow,' 3 February.

FSB (Financial Stability Board) (2012): Global shadow banking monitoring report 2012, 18 November, URL: http://www.financialstabilityboard.org/publications/r_121118c.pdf.

Galbraith, J.K. (1975): Money: From Whence It Came, Where It Went, Boston: Houghton Mifflin.

Galbraith, J.K. (1990): A Short History of Financial Euphoria, New York: Penguin.

Gorton, G. (2009): Slapped in the face by the invisible hand: banking and the panic of 2007, paper prepared for the Federal Reserve Bank of Atlanta's 2009 financial markets conference: financial innovation and crisis, 11-13 May, URL: http://www.frbatlanta.org/news/conferen/09fmc/ gorton.pdf.

Gorton, G. (2010): Questions and answers about the financial crisis, prepared for the U.S. Financial Crisis Inquiry Commission, 20 February, URL: http://online.wsj.com/public/resources/documents/crisisqa0210.pdf.

Gorton, G., Metrick, A. (2010): Haircuts, in: Federal Reserve Bank of St. Louis Review, November/ December, 507-520.

Gorton, G., Souleles, N. (2007): Special purpose vehicles and securitization, in: Carey, M., Stulz, R. (eds), The Risks of Financial Institutions, Chicago: University of Chicago Press, 549-602.

Greenspan, A. (2005): Remarks by Chairman Alan Greenspan: economic flexibility before the National Italian American Foundation, 12 October, Washington, DC, URL: http://www. federalreserve.gov/boarddocs/speeches/2005/20051012/.

IMF (International Monetary Fund) (2008): Structured finance: issues of valuation and disclosure, in: Global Financial Stability Report, Washington, DC.

Jeffers, E., Plihon, D. (2013): Le shadow banking system et la crise financière, in: Cahiers Française, July/August, $50-57$.

Juks, R. (2012): Asset encumbrance and its relevance for financial stability, in: Sveriges Riksbank Economic Review, 3, 67-89.

Kindleberger, Charles P. (1989): Manias, Panics and Crashes: A History of Financial Crises, New York and London: Basic Books.

Lewis, M. (2010): The Big Short: Inside the Doomsday Machine, New York: W.W. Norton.

Marshall, W. (2009): Friends helping friends: lessons from the Mexican bank bailout for the United States, in: Economia Informa, 356, 145-160.

Meyer, G., Stafford, P. (2013): ABN AMRO broker to pay $\$ 1 \mathrm{~m}$ to settle customer account shortfalls, Financial Times, 19 June, URL: http://www.ft.com/intl/cms/s/0/e42b5c3a-d8f1-11e284fa-00144feab7de.html\#axzz2zXEyNHc0.

OCC (Office of the Comptroller of the Currency) (2013): OCC's quarterly report on bank trading and derivatives activities, first quarter, 2013, graph 4, URL: http://www.occ.gov/topics/capitalmarkets/financial-markets/trading/derivatives/dq113.pdf.

OECD (2011): Bank Competition and Financial Stability, OECD publishing, 36, URL: http:// www.oecd.org/finance/financial-markets/48501035.pdf.

Olaoye, E., Elias, C. (2011): MF Global trustee reviewing firm's practice of repledging collateral, Reuters, URL: http://blogs.reuters.com/financial-regulatory-forum/2011/12/21/mf-global-trustee-reviewing-firms-practice-of-repledging-collateral/.

Pozsar, Z., Adrian, T., Ashcraft, A., Boesky, H. (2010): Shadow banking, in: Federal Reserve Bank of New York Staff Reports, 458, 4 December.

Rehault, P. (2013): Understanding shadow banking from a European perspective; draft version, URL: http://afse2013.sciencesconf.org/conference/afse2013/pages/rehaultperspective_AFSE.pdf. 
Sawyer, M. (2013): Endogenous money, circuits and financialization, in: Review of Keynesian Economics, 1(2), 230-241.

Scannell, K. (2013): UBS to pay \$50m to settle SEC charges, Financial Times, URL: http://www.ft. $\mathrm{com} / \mathrm{intl} / \mathrm{cms} / \mathrm{s} / 0 / \mathrm{ceff1}$ 824-fec1-11e2-b9b0-00144feabdc0.html\#axzz2zXEyNHc0.

Schwarcz, S. (1994): The alchemy of asset securitization, in: Stanford Journal of Law, Business \& Finance, 1, 133-154.

Singh, M. (2011): Velocity of pledged capital: analysis and implications, IMF working paper, November.

Singh, M., Aitken, J. (2010): The (sizable) role of rehypothecation in the shadow banking system, IMF working paper, monetary and capital markets department, July.

Tett, Gillian (2009): Watch Barclay's in the cellar, Financial Times, 17 September, URL: http:// www.ft.com/intl/cms/s/0/178ea472-a3b5-11de-9fed-00144feabdc0.html.

ZeroHedge (2011): Why the UK trail of the MF Global collapse may have 'apocalyptic' consequences for the Eurozone, Canadian Banks, Jefferies and everyone else, URL: http://www.zerohedge.com/ news/why-uk-trail-mf-global-collapse-may-have-apocalyptic-consequences-eurozone-canadianbanks-jeffe.

ZeroHedge (2013): Peak collateral, URL: http://www.zerohedge.com/news/2013-05-27/peakcollateral. 